\title{
ANALISIS TINGKAT HUBUNGAN KARAKTER JUJUR SISWA TERHADAP HASIL BELAJAR IPA TERPADU
}

\author{
Cicyn Riantoni' ${ }^{1)}$, Arip Nurrahman ${ }^{2)}$ \\ ${ }^{1}$ Fakultas Keguruan dan Ilmu Pendidikan, Universitas Jambi \\ email: cicynriantoni12@gmail.com \\ ${ }^{2}$ Fakultas Keguruan dan Ilmu Pendidikan, Universitas Jambi \\ email: aripnurrahman17@gmail.com
}

\begin{abstract}
This research aims to analyze the relationship between students' honest character towards the learning outcomes of integrated science in calor and its transfer material in SMP Negeri 6 Kota Jambi, and analyze the level of relations of the two variables. The method used in this research is descriptive quantitative method. The population in this research were 61 students of class VIIA and VIIB SMP Negeri 6 Kota Jambi. The Data in this research were obtained by the results of filling out questionnaires and quiz distributed directly to the subject, as well as documentation and observation techniques. The data analysis in this research used descriptive statistical calculations. The results of the analysis show that there is a significant relationship between students' honest character towards integrated science learning outcomes. The level of relationship between students' honest character toward integrated science learning outcomes is in a very strong category where the Pearson Correlations value is obtained at 0.919. Thus, if the higher the level of honesty of students, the higher the learning outcomes that will be achieved, in this case on integrated science subjects.
\end{abstract}

Keyword: Character education, Honest, Learning outcomes

Abstrak: Penelitian ini bertujuan untuk menganalisis hubungan antara karakter jujur siswa terhadap hasil belajar IPA terpadu materi kalor dan perpindahannya di SMP Negeri 6 Kota Jambi, serta menganalisis tingkat hubungan dari kedua variabel tersebut. Metode yang digunakan dalam penelitian ini adalah metode deskriptif kuantitaf. Populasi dalam penelitian ini adalah 61 siswa kelas VIIA dan VIIB SMP Negeri 6 Kota Jambi. Data dalam penelitian ini diperoleh dari hasil pengisian angket dan kuesioner yang disebarkan langsung ke subjek, serta dilakukan teknik dokumentasi dan observasi. Analisis data dalam penelitian ini menggunakan perhitungan statistik deskriptif. Hasil analisis menunjukkan bahwa terdapat hubungan yang signifikan antara karakter jujur siswa terhadap hasil belajar IPA terpadu. Tingkat hubungan karakter jujur siswa terhadap hasil belajar IPA terpadu berada pada kategori sangat kuat dimana nilai Pearson Correlations diperoleh sebesar 0,919. Dengan demikian, apabila semakin tinggi tingkat kejujuran siswa, maka semakin tinggi pula hasil belajar yang akan dicapai, dalam hal ini pada mata pelajaran IPA terpadu.

Kata kunci: Pendidikan karakter, Jujur, Hasil belajar

\section{PENDAHULUAN}

Sejak keberadaan manusia di bumi, maka sejak itu pula hakikatnya telah ada kegiatan pendidikan dan pengajaran. Berbeda dengan masa sekarang, dimana pendidikan dan pengajaran diselenggarakan di sekolah. Sedangkan Pendidikan adalah proses internalisasi budaya ke dalam diri seseorang dan masyarakat sehingga membuat orang dan masyarakat jadi beradab. Pendidikan bukan merupakan sarana transfer ilmu pengetahuan saja, tetapi lebih luas lagi yakni sebagai sarana pembudayaan dan penyaluran nilai (enkulturisasi dan sosialisasi). Anak harus mendapatkan pendidikan yang menyentuh dimensi dasar kemanusiaan. Selanjutnya tujuan pendidikan adalah untuk 
mengembangkan diri dan meningkatkan kemampuan, baik secara afektif, kognitif, dan psikomotorik (Prasasty, 2017: 65).

Pendidikan memegang peranan penting dalam upaya pengembangan sumber daya manusia dan menentukan kemajuan suatu bangsa. Dengan kata lain pendidikan merupakan faktor utama yang berpengaruh dalam menghadapi era globalisasi. Saat ini sistem pendidikan telah mengalami kemajuan yang sangat pesat. Sekolah sebagai lembaga yang menyelenggarakan pendidikan berfungsi untuk menyeleksi manusia berbakat, menciptakan manusia yang berkarakter, terampil dan mampu membawa manusia berkembang ke arah kondisi yang dipersyaratkan oleh masa depan bangsa.

Sementara itu Sukardjo (2018:102) mengatakan bahwa sekolah merupakan laboratorium bagi siswa untuk belajar memecahkan masalah karena setiap siswa memiliki kebutuhan untuk menyelidiki lingkungan mereka dan membangun secara pribadi pengetahuannya. Melalui kegiatan tersebut siswa menemukan ide mereka sendiri dan memperoleh makna oleh mereka sendiri. Guru sebagai fasilitator memberi bimbingan kepada siswa guna mengatasi masalah yang melampaui tingkat perkembangan saat itu. Artinya, siswa memperoleh sendiri pengetahuannya dan guru lebih berperan sebagai fasilitator dan membimbing siswa pada proses belajarnya.

Pendidikan harus mencakup tiga hal yakni aspek kognitif, aspek afektif, dan aspek psikomotorik. Aspek kognitif semata yang menjadi tujuan utama dalam pembelajaran maka fungsi pendidikan nasional dan tujuan pendidikan nasional akan sulit terwujud. Guru sebagai institusi pendidikan harus menyadari akan tanggung jawab sebagai pendidik untuk memperhatikan anak didiknya terutama dalam pendidikan karakter agar menghasilkan alumnus yang berkarakter. Pendidikan karakter bukan sekedar mengajarkan mana yang benar dan mana yang salah akan tetapi lebih dari itu. Pendidikan karakter menanamkan kebiasaan tentang hal mana yang baik sehingga peserta didik menjadi paham tentang mana yang benar dan salah, mampu merasakan nilai yang baik dan biasa melakukannya.

Definisi diatas dapat disimpulkan bahwa pendidikan tidak hanya mendidik para peserta didiknya untuk menjadi manusia yang cerdas saja, tetapi juga membangun kepribadiannya agar berakhlak mulia. Pendidikan juga dapat diartikan sebagai salah satu usaha yang dilakukan secara sadar dan sengaja untuk mengubah tingkah laku manusia baik secara individu maupun kelompok untuk mendewasakan manusia melalui pengajaran dan pelatihan. Menurut Hardiyanti (2018: 3), sikap (attitude) adalah pikiran dan perasaan yang mendorong kita bertingkah laku ketika kita menyukai atau tidak menyukai sesuatu. Sedangkan sikap itu sendiri mengandung tiga komponen yaitu: kognitif, emosi dan perilaku serta bisa konsisten dan bisa juga tidak tergantung permasalahan apa yang mereka hadapi

Karakter menurut Foerster (1966) dalam Adisusilo (2014: 76), adalah sesuatu yang mengualifikasi seorang pribadi. Karakter menjadi identitas, menjadi ciri, menjadi sifat yang tetap, yang mengatasi pengalaman kontingen yang selalu berubah. Jadi karakter adalah seperangkat nilai yang telah menjadi kebiasaan hidup sehingga menjadi sifat tetap dalam diri seseorang, misalnya kerja keras, pantang menyerah, jujur, sederhana, dan lain-lain. Dengan karakter itulah kualitas seorang pribadi diukur. Sedangkan tujuan pendidikan karakter adalah terwujudnya kesatuan esensial si subjek dengan pelaku dan sikap/nilai hidup yang dimilikinya. Jadi, pendidikan karakter dapat dilakukan dengan pendidikan nilai pada diri seseorang.

Karakter seseorang perlu dikembangkan ke arah yang positif. Nilainilai karakter tersebut mengandung nilainilai kebajikan yang berupa kejujuran, moral, norma, dan tingkah laku orang dalam perbuatan. Pengembangan karakter bangsa dapat dilakukan melalui pengembangan karakter individu itu sendiri. Manusia hidup dalam lingkungan sosial dan budaya tertentu, maka pengembangan karakter individu seseorang hanya dapat 
dilakukan dalam lingkungan sosial dan budaya yang bersangkutan.

Nilai-nilai pendidikan karakter perlu dijabarkan sehingga diperoleh deskripsinya. Deskripsi berguna sebagai batasan atau tolak ukur ketercapain pelaksanaan nilainilai pendidikan karakter di sekolah. Menurut Kementerian Pendidikan Nasional dalam Alimin (2014: 19), Jujur adalah seseorang dalam hal ini khususnya siswa selalu berusaha untuk menjadikan dirinya sebagai seorang siswa yang selalu dapat dipercaya baik perkataan, tindakan maupun pekerjaannya. Kejujuran seseorang siswa dapat dilihat melalui perkataan, tindakan maupun pekerjaannya dalam kehidupan sehari-harinya baik disekolah, keluarga maupun lingkungan masyarakat. Perkataan seorang siswa yang jujur dapat dipercaya karena perkataanya sesuai dengan kenyataan yang terjadi.Tindakan dan pekerjaan seorang siswa yang jujur selalu dilakukan sesuai aturan dan tidak melakukan kecurangan.Kejujuran siswa juga dapat dilihat pada saat mengerjakan tugas tugas yang diberikan oleh guru dan juga pada saat ujian.

Sedangkan menurut Mustari (2014: 13), jujur bermakna keselarasan antara berita dengan kenyataan yang ada. Ada beberapa tingkatan kejujuran, demikian Kong Fu Tse: (1) $L i$, ingin tampak benar untuk kemampuan pribadi; (2) $Y i$, mengatakan apa yang benar atas dasar bahwa kita akan diperlakukan secara sama; (3) Ren, berdasarkan bentuk yang paling mulia dari empati terhadap yang lain yang berbeda dari kita baik secara umur, jenis kelamin, budaya, pengalaman, keluarga, dan sebagainya. Kejujuran itu ada pada ucapan, juga ada pada perbuatan, sebagaimana seorang yang melakukan suatu perbuatan, tentu sesuai dengan yang ada pada batinnya.

Siswa yang tidak jujur dalam mengerjakan tugas maupun saat ujian pasti berpengaruh pula pada prestasi belajar mereka. Hamalik (2008) dalam Syamsudin (2012: 3) menyatakan bahwa dalam lembaga pendidikan, prestasi belajar merupakan indikator yang penting untuk mengukur keberhasilan proses belajar mengajar. Prestasi belajar adalah penguasaan pengetahuan atau ketrampilan yang dikembangkan oleh mata pelajaran, lazimnya ditunjukkan dengan nilai tes yang diberikan oleh guru. Prestasi individu adalah hal yang telah dicapai oleh seseorang yang disebut prestasi belajar.

Menurut Muhibbin (2006: 144), prestasi belajar siswa dipengaruhi oleh setidaknya tiga faktor yakni: (1) Faktor internal (faktor dari dalam siswa), yakni keadaan/kondisi jasmani dan rohani siswa; (2) Faktor eksternal (faktor dari luar siswa), yakni kondisi lingkungan di sekitar siswa; (3) Faktor pendekatan belajar (approach to learning), yakni jenis upaya belajar siswa yang meliputi strategi dan metode yang digunakan siswa untuk melakukan kegiatan pembelajaran materi-materi pelajaran.

Nana Sudjana (2005) dalam Alimin (2014: 28), menjelaskan hasil belajar adalah kemampuan-kemampuan yang dimiliki siswa setelah menerima pengalaman belajar. Hasil belajar merupakan perilaku berupa pengetahuan, keterampilan, sikap, informasi, strategi kognitif yang baru dan diperoleh siswa setelah berinteraksi dengan lingkungan dalam suatu suasana atau kondisi pembelajaran. prestasi belajar adalah tingkat keberhasilan yang dicapai dari suatu kegiatan atau usaha yang dapat memberikan kepuasan emosional, dan dapat diukur dengan alat atau tes tertentu serta menyebabkan terjadinya perubahan kognitif, afektif, maupun psikomotorik.

Husamah et al. (2016) dalam Janah (2018: 3), menjelaskan bahwa mata pelajaran IPA adalah suatu mata pelajaran yang memuat kumpulan teori yang sistematis, penerapannya secara umum terbatas pada gejala alam, lahir dan berkembang melalui metode ilmiah seperti observasi dan eksperimen serta menuntut sikap ilmiah seperti rasa ingin tahu, terbuka, jujur, dan sebagainya. Pada proses pembelajaran IPA, biasanya guru cenderung untuk menjelaskan maupun memberitahukan segala sesuatunya kepada siswa, sehingga siswa menjadi tidak terbiasa belajar lebih aktif. Hal ini menunjukkan bahwa peran guru sangat penting dalam pelaksanaan proses belajar mengajar, dan dapat dikatakan bahwa kualitas pendidikan di sekolah sangat 
ditentukan oleh kemampuan guru dalam mengelola proses belajar mengajar. Idealnya, seorang guru bukan hanya menjelaskan materi saja tetapi juga harus menanamkan nilai-nilai karakter pada setiap individu peserta didiknya.

Permasalahan ini juga pernah dikaji dalam penelitian Fitri (2016: 99) dengan judul Pengaruh Sikap Kedisiplinan dan Kejujuran Peserta Didik terhadap Hasil Belajar Biologi. Berdasarkan hasil penelitian tersebut, dapat disimpulkan bahwa sikap kejujuran siswa kelas VIII SMP Negeri 2 Bajeng Barat Kab. Gowa dalam kategori sedang yaitu sebesar $69,4 \%$ serta hasil belajar siswa yang memiliki sikap kedisiplinan tidak jauh berbeda dengan hasil belajar siswa yang memiliki sikap kejujuran. Namun kekurangan dari penelitian ini yaitu hasil penelitian hanya menyajikan hubungan antara sikap kedisiplinan dan kejujuran terhadap hasil belajar siswa saja. Sedangkan penelitian ini akan menyajikan hubungan karakter jujur siswa terhadap hasil belajar IPA terpadu materi kalor dan perpindahannya, serta tingkat hubungan dari kedua variabel tersebut. Penelitian ini diharapkan akan mampu memberikan manfaat bagi peserta didik berupa pengalaman baru dan menjadi lebih termotivasi, dan bagi guru berupa informasi tentang kondisi peserta didik sehingga dapat menjadi acuan dalam upaya meningkatkan character building terutama kejujuran peserta didik.

\section{METODE PENELITIAN}

Penelitian ini berlokasi di SMP Negeri 6 Kota Jambi. Metode yang digunakan dalam penelitian ini adalah metode deskriptif kuantitaf. Subjek berasal dari dua kelas, yaitu VIIA dan VIIB tahun ajaran 2018/2019 dengan jumlah total keseluruhannya 61 siswa.

Teknik pengumpulan data dari penelitian ini diperoleh dari hasil pengisian angket dan kuesioner yang disebarkan langsung ke subjek. Angket terdiri dari 25 pertanyaan tertutup mengenai kesadaran siswa dalam berperilaku jujur di kelas, penilaian angket dilakukan dengan menggunakan skala Likert. Jawaban setiap instrumen mempunyai gradasi dari sangat positif sampai sangat negatif, yang dapat berupa kata-kata antara lain: (a) selalu; (b) sering; (c) jarang; (d) tidak pernah. Untuk kepentingan analisis kuantitatif maka jawaban itu diberi skor: (a) selalu diberi skor 4; (b) sering diberi skor 3; (c) jarang diberi skor 2; dan (d) tidak pernah diberi skor 1. Sedangkan untuk soal yang diberikan terdiri atas 30 soal pilihan ganda materi kalor dan perpindahannya. Bobot personal jika menjawab benar bernilai 1 dan jika salah bernilai 0, sehingga skor maksimum keseluruhan menjadi 30. Adapun analisis data dalam penelitian ini menggunakan perhitungan statistik deskriptif dengan bantuan program SPSS 25.0 (Statistical Packages for Social Sciences). Dimana dilakukan uji normalitas dan uji linier terlebih dahulu untuk melihat apakah data akan dianalisis secara parametrik atau non-parametrik.

\section{HASIL DAN PEMBAHASAN}

\section{Analisis Karakter Jujur Siswa}

Tabel 1. Kategorisasi Karakter Jujur Siswa Kelas VII di SMP Negeri 6 Kota Jambi

\begin{tabular}{cccc}
\hline Interval Skor & Frekuensi & Kategori & Persentase (\%) \\
\hline $25,00-43,75$ & 0 & Sangat Tidak Baik & 0 \\
\hline $43,76-62,50$ & 2 & Tidak Baik & 3,28 \\
\hline $62,51-81,25$ & 29 & Baik & 47,54 \\
\hline $81,26-100,00$ & 30 & Sangat Baik & 49,18 \\
\hline Jumlah & 61 & & 100
\end{tabular}

Untuk menganalisis karakter jujur siswa kelas VII di SMP Negeri 6 Kota Jambi, ditinjau dari segi penilaian skala Likert. Berdasarkan data pada Tabel 1, terdapat 2 siswa yang menjawab angket dalam kategori "Tidak Baik" dengan persentase sebesar 3,28\%. Sementara itu ada 29 siswa yang menjawab angket dalam 
kategori "Baik" dengan persentase sebesar 47,54 \%. Sedangkan 30 siswa lainnya menjawab angket dalam kategori "Sangat Baik" dengan persentase 49,18\%. Berdasarkan parameter-parameter yang telah dijelaskan, dapat disimpulkan bahwa tingkat karakter jujur siswa kelas VII berada dalam kategori "Sangat Baik".

\section{Analisis Hasil Belajar Siswa}

Berdasarkan data hasil observasi di kelas VII SMP Negeri 6 Kota Jambi, didapatkan nilai rata-rata (mean) dari 61 siswa sebesar 51,69. Sedangkan untuk nilai tengah (median) didapatkan hasil sebesar 53,33 . Sementara untuk nilai yang sering muncul (modus) didapatkan hasil sebesar 53,33 . Untuk standar deviasi didapatkan hasil sebesar 13,48, nilai minimum sebesar 20,00 dan nilai maksimum sebesar 80,00, serta rentang data sebesar 60,00. Standar deviasi digunakan untuk menentukan valid atau tidaknya suatu data, apabila nilai standar deviasi lebih kecil dari nilai mean, maka data tersebut adalah valid. Dari data yang telah diperoleh, diketahui nilai standar deviasi sebesar 13,48, dimana nilainya lebih kecil daripada nilai mean yaitu sebesar 51,69 , maka data dianggap valid.
Uji normaltas bertujuan untuk menyelidiki apakah data berdistribisi normal atau tidak. Berdasarkan data yang telah diperoleh nilai signifikasi masingmasing variabel, untuk angket karakter siswa didapatkan hasil sebesar 0,065, sedangkan untuk hasil belajar siswa didapatkan hasil sebesar 0,171. Data yang diperoleh dapat dikatakan terdistribusi normal karena setiap variabel memiliki nilai probabilitas yang lebih besar dari 0,05 .

\section{Uji Homogenitas}

Uji homogenitas bertujuan untuk mengetahui apakah angket karakter yang diberikan di kelas VIIA dan VIIB bersifat homogen (sejenis). Berdasarhan hasil uji homogenitas diperoleh nilai sig 0,598 atau lebih besar dari 0,05 , sehingga dapat disimpulkan bahwa kedua data memiliki varians yang homogen. Setelah data hasil dilakukan uji asumsi yaitu uji normalitas dan homogenitas, selanjutnya data akan dilakukan uji lanjut yaitu uji parametrik untuk mengamati apakah ada korelasi antara angket karakter jujur dengan hasil belajar siswa.

\section{Uji Korelasi}

\section{Uji Normalitas}

Tabel 2. Hasil Uji Pearson Product Moment

\begin{tabular}{llcc}
\hline \multicolumn{4}{c}{ Correlations } \\
\hline \multirow{2}{*}{ Angket karakter } & Pearson Correlation & Angket karakter & Hasil belajar \\
& Sig. (2-tailed) & 1 & $.919^{* *}$ \\
& $\mathrm{~N}$ & 61 & .000 \\
\hline Hasil belajar & Pearson Correlation & $.919^{* *}$ & 61 \\
& Sig. (2-tailed) & .000 & 1 \\
& $\mathrm{~N}$ & 61 & 61 \\
\hline
\end{tabular}

Berdasarkan data pada Tabel 2 menunjukan bahwa variabel angket karakter memiliki nilai signifikansi (Sig.) sebesar 0,000 pada baris Sig. (2-tailed) dengan nilai $\alpha$ (derajat signifkansi) sebesar 0,05 , maka $0,000<0,05$ hal ini menunujukan bahwa terdapat hubungan variabel angket karakter jujur siswa terhadap hasil belajar IPA terpadu. Selanjutnya pada baris Pearson Correlations diperoleh nilai sebesar 0,919 artinya tingkat hubungan variabel angket karakter jujur siswa terhadap hasil belajar IPA terpadu berada dalam kategori "sangat kuat". Pada baris Pearson Correlations juga diperoleh hasil yang positif (+) artinya semakin tinggi tingkat kejujuran siswa, maka hasil belajar IPA terpadu juga akan semakin meningkat. Berdasarkan parameter-parameter yang telah dijelaskan, dapat disimpulkan bahwa hubungan antara karakter jujur siswa dan hasil belajar IPA 
terpadu berada pada kategori sangat kuat, sehingga siswa yang berperilaku jujur dengan baik, maka akan mempunyai hasil belajar IPA terpadu yang lebih baik.

Untuk membuktikan pernyataan diatas, peneliti melakukan observasi terhadap dua siswa yang memiliki nilai angket karakter rendah dan tinggi. hal ini dilakukan untuk mengamati korelasi nilai angket karakter siswa dengan hasil belajarnya. Hasil observasi menunjukkan bahwa siswa pertama yang memiliki nilai angket karakter rendah juga mendapatkan hasil belajar yang relatif rendah. Dimana nilai angket karakter yang diperoleh siswa pertama adalah sebesar 62 artinya karakter jujur siswa pertama berada pada kategori "tidak baik". Adapun hasil belajar yang diperoleh siswa pertama sebesar 43,33 (sebagaimana ditunjukkan pada Gambar 1) artinya hasil belajar siswa berada dibawah mean yaitu sebesar 51,69, hal ini menunjukkan bahwa hasil belajar siswa berada dalam kategori "rendah".

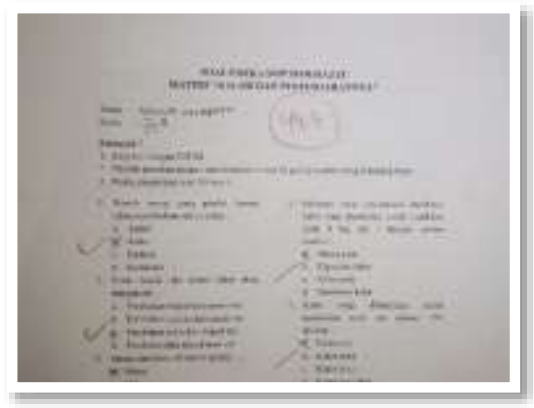

Hasil observasi selanjutnya menunjukkan bahwa siswa kedua yang memiliki nilai angket karakter tinggi juga mendapatkan hasil belajar yang tinggi. Dimana nilai angket karakter yang diperoleh siswa kedua adalah sebesar 86 artinya karakter jujur siswa pertama berada

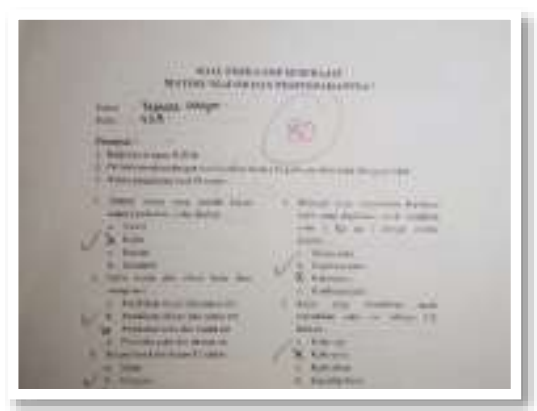

Gambar 2. Hasil Belajar Siswa Kedua

Berdasarkan pemaparan diatas, peneliti dapat menyimpulkan bahwa ada korelasi atau hubungan antara karakter jujur siswa dengan hasil belajarnya dimana apabila siswa memiliki nilai angket karakter yang rendah, maka hasil belajarnya juga relatif rendah. Sedangkan siswa yang memiliki nilai angket karakter tinggi, maka hasil belajarnya juga akan tinggi. Hasil ini sejalan dengan penelitian sebelumnya yang dilakukan oleh Prasasty (2017: 72) yang menyatakan bahwa hubungan antara variabel motivasi, disiplin, dan prestasi belajar pada taraf kuat, sehingga anak yang mempunyai motivasi dan disiplin yang baik, maka akan mempunyai prestasi belajar yang lebih baik. Karakter motivasi dan disiplin berkaitan erat dengan karakter jujur, dimana ketiga karakter ini sama-sama dimuat dalam 18 karakter yang wajib diterapkan di setiap tingkat satuan pendidikan.

Hasil penelitian ini relevan dengan penelitian Fitri (2016) yang menyatakan 
bahwa berdasarkan hasil analisis statistik inferensial sikap kedisiplinan dan kejujuran berpengaruh terhadap hasil belajar Biologi peserta didik Kelas VIII SMP Negeri 2 Bajeng Barat Kab.Gowa. Sumbangan pengaruh variabel sikap kedisiplinan dan kejujuran sebesar 90,5\% dan sisanya 9,5\% dipengaruhi oleh variabel lain yang tidak dimasukkan dalam penelitian ini, seperti minat, motivasi, gaya belajar dan lain sebagainya.

\section{SIMPULAN}

Berdasarkan temuan-temuan dalam penelitian ini, dapat disimpulkan bahwa terdapat hubungan yang signifikan antara karakter jujur siswa terhadap hasil belajar IPA terpadu. Tingkat hubungan karakter jujur siswa terhadap hasil belajar IPA terpadu berada pada kategori sangat kuat dimana nilai Pearson Correlations diperoleh sebesar 0,919. Dengan demikian, apabila semakin tinggi tingkat kejujuran siswa, maka semakin tinggi pula hasil belajar yang akan dicapai, dalam hal ini pada mata pelajaran IPA terpadu.

\section{DAFTAR RUJUKAN}

Adisusilo, S. (2014). Pembelajaran NilaiKarakter. Jakarta: Rajawali Pers.

Alimin, A. (2014). Pengaruh Pendidikan Karakter terhadap Prestasi Belajar Mata Pelajaran Produktif Siswa Kompetensi Keahlian Teknik Elektronika Industri SMK $N \quad 1$ Losarang Kabupaten Indramayu. Skripsi. Yogyakarta: Universitas Negeri Yogyakarta.

Fitri, N, Safei, Marjuni, H. (2016). Pengaruh Sikap Kedisiplinan dan Kejujuran Peserta Didik terhadap Hasil Belajar Biologi. Jurnal Biotek, 4 (1), 99.
Hardiyanti, K, Astalini, Kurniawan, D, A. (2018). Sikap Siswa terhadap Mata Pelajaran Fisika di SMA Negeri 5 Muaro Jambi. Jurnal Edufisika, 3 (2), 3.

Janah, I, N, Chamisijatin, L, Husamah. (2018). Implementasi Pendidikan Karakter dalam Pembelajaran IPA di SMPN XY Kota Malang. Jurnal Biotek, 6 (1), 3.

Muhibbin, Syah. (2006). Psikologi Belajar dan Mengajar. Bandung: Sinar Baru Algensido.

Mustari, M. (2014). Nilai Karakter: Refleksi untuk Pendidikan. Jakarta: Rajawali Pers.

Prasasty, A, T. (2017). Pengaruh Disiplin dan Motivasi Belajar terhadap Prestasi Belajar Matematika Siswa Kelas X SMK Bina Karya Insan Tangerang Selatan. UTILITY: Jurnal Ilmiah Pendidikan dan Ekonomi, 1 (1), 65.

Sukardjo, M, Yusdiningtias, K. (2018). Pengaruh Strategi Pembelajaran dan Kecerdasan Logis Matematis terhadap Hasil Belajar Matematika Sekolah Dasar Kelas VI. Jurnal Pendidikan Edutama, 5 (1), 102.

Syamsudin. (2012). Pengaruh Kejujuran dalam Mengerjakan Tugas Terhadap Prestasi Belajar Matematika Siswa Kelas VIII SMP $N \quad 1$ Jaten Karanganyar ditinjau dari Jenis Kelamin. Naskah Publikasi. Surakarta: Universitas Muhammadiyah Surakarta. 
8 JURNAL PENDIDIKAN EDUTAMA, Vol. 7, No. 2 Juli, 2020 